\title{
Reduction of prejudice toward unaccompanied foreign minors through audiovisual narratives. Effects of the similarity and of the narrative voice
}

\author{
Iñigo Guerrero-Martín; Juan-José Igartua
}

How to cite this article:

Guerrero-Martín, Iñigo; Igartua, Juan-José (2021). "Reduction of prejudice toward unaccompanied foreign minors through audiovisual narratives. Effects of the similarity and of the narrative voice". Profesional de la información, v. 30, n. 2, e300203.

https://doi.org/10.3145/epi.2021.mar.03

Manuscript received on February $8^{\text {th }}, 2021$ Accepted on February $30^{\text {th }}, 2021$

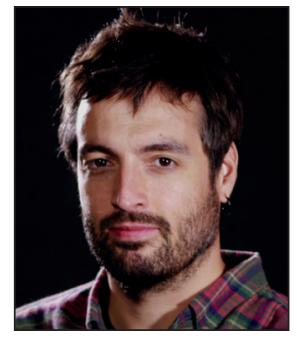

Iñigo Guerrero-Martín

https://orcid.org/0000-0002-1135-1098

University of Salamanca

Dep. of Sociology and Communication

Avda. Francisco Tomás y Valiente

Campus Unamuno, Edificio FES

37007 Salamanca, Spain

i.guerrero@usal.es

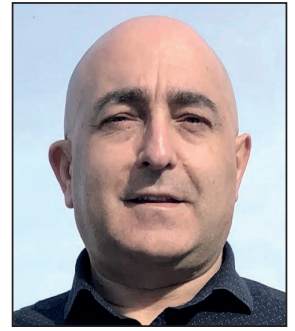

Juan-José Igartua

https://orcid.org/0000-0002-9865-2714

University of Salamanca

Dep. of Sociology and Communication

Avda. Francisco Tomás y Valiente

Campus Unamuno, Edificio FES

37007 Salamanca, Spain

jigartua@usal.es

\begin{abstract}
This study focuses on the reduction of prejudice toward foreign unaccompanied minors (UAMs) by means of audiovisual testimonial messages. Specifically, it analyzes the role of two narrative elements that can influence, in an indirect way, the intention to share the message, the feelings toward UAMs, the intention to approach UAMs, and the intention to collaborate with an NGO that provides support to immigrants. With this goal in mind, an experimental study $(N=500)$ was conducted using a $2 \times 2$ factorial design, where the factors analyzed were similarity in terms of social identity (high vs. low) and narrative voice (first-person vs. third-person). No interaction effects of similarity and narrative voice on identification or transportation were observed. However, multiple serial mediation analyses were statistically significant. A significant indirect effect of similarity on dependent variables was observed through perceived similarity (primary mediator), identification and transportation (secondary mediators), and counterarguing and reactance (tertiary mediators). Similarly, the narrative voice also had a significant indirect effect on the dependent variables that was explained by the increase in identification and transportation, and by the reduction in counterarguing and reactance. This work improves the understanding of the mechanisms that explain the impact of narratives and demonstrates that certain narrative elements can increase the effectiveness of audiovisual testimonial messages designed for the prevention of racism and xenophobia.
\end{abstract}

\section{Keywords}

Narrative persuasion; Audience-character similarity; Narrative voice; Prejudice reduction; Immigration; Mediation analysis; Testimonial messages; Identification with the protagonist; Transportation; Counterarguing; Reactance.

Funding

This work has been made possible thanks to the financial support of Castilla y León Regional Government's Ministry of Education and the European Social Fund through a Grant for hiring research personnel in training (EDU/574/2018); as well as the Ministry of Science and Innovation that, through the National Programme for Fostering Excellence in Scientific and Technical Research, finances the "Narrative tools to reduce prejudice, effects of similarity, imagined contact, empathy and narrative voice" (CSO2015-67611-P), the project from which this research is derived. 


\section{Introduction}

Despite the fact that we live in multicultural societies, the feeling of rejection and mistrust towards immigrants is still very frequent among the native population. In fact, prejudice toward immigrants is a very present problem in Spain. According to the 2019 Report on the evolution of hate crimes in Spain, 515 crimes related to racism and xenophobia were recorded in Spain in 2019, which represents an increase of almost 21\% with respect to 2018 (Ministry of Home Affairs, 2020). Moreover, according to the latest survey of Attitudes toward immigration, more than $61 \%$ of those interviewed thought that the number of immigrants in Spain was "excessive" or "high"; and 37\% thought that Spaniards treated immigrants with "mistrust", "contempt" or "aggressiveness" (CIS, Sociological Research Centre, 2017).

Within the immigrant population, there is a particularly vulnerable group known as "unaccompanied foreign minors" or UAMs. In Spain it is widely used the term MENAs (for its Spanish acronym), however, throughout this article, the term UAMs (for unaccompanied minors) will be used, which is the more globally consensual to refer to this group. According to the Directive 2011/95/EU of the European Parliament and the Council of the European Union, an UAM is a

"minor who arrives on the territory of an EU Member unaccompanied by the adult responsible for them by law or by the practice of the EU Member State concerned, and for as long as they are not effectively taken into the care of such a person; or who is left unaccompanied after they have entered the territory of the EU Member State".

This group faces a situation of special vulnerability because of their condition of minors, foreigners, and separated from their parents. Moreover, this group is suffering a great rejection by Spanish society as the result of an increasingly hostile public opinion towards immigrants and inadequate media treatment which emphasize their presence in the country with the increase of delinquency (Gómez-Quintero; Aguerri; Gimeno-Monterde, 2021; Manzani; Arnoso, 2014; Mercader, 2019).

Likewise, hostile positions towards UAMs are also present in public opinion in other countries in the European context. For example, in an investigation carried out in Thessaloniki (Greece), it was observed that both communities and local institutions perceive these minors as criminals who threaten public peace (Kovner; Zehavi; Golan, 2021). Similarly, in a survey carried out in Germany $(N=2524)$, Plener et al. (2017) found that only $22.8 \%$ of the participants were in favor of receiving more UAMs in the country, and that the majority defended the immediate deportation of unaccompanied minors from the Balkans (62\%) and Africa (51,1\%).

In this context of social tension, it is a priority to design effective strategies to reduce prejudice towards UAMs. This paper focuses on the reduction of prejudice toward "unaccompanied foreign minors" in Spain by using audiovisual narratives featuring a minor of Moroccan origin (testimonials). The choice of a minor of Moroccan origin as the protagonist of the story is due to the fact that most unaccompanied migrant children arriving in Spain come mainly from Morocco (López-Belmonte et al., 2019), and that it is precisely immigrants of Moroccan origin who generate the least sympathy among Spaniards (CIS, 2017).

\author{
This paper focuses on the reduction of \\ prejudice toward "unaccompanied fo- \\ reign minors" in Spain by using audio- \\ visual narratives featuring a minor of \\ Moroccan origin (testimonials)
}

\section{Mediated intergroup contact, narrative persuasion and prejudice reduction}

In the field of social psychology, different strategies have been developed with the aim of reducing prejudice toward discriminated groups. One of the most relevant intervention approaches is based on Contact Theory (Allport, 1954), which states that facilitating direct contact between ingroup and outgroup members is an effective way to reduce the prejudice. In this sense, meta-analytic empirical evidence has found a negative correlation between contact and prejudice (Pettigrew; Tropp, 2006).

However, it has also been observed that the positive effects of intergroup contact can occur through forms of indirect contact, such as the media and, in particular, through narrative messages (Park, 2012). In this context, mediated intergroup contact is defined as the parasocial interaction between a spectator who belongs to the ingroup and the protagonist of a narrative who is part of an outgroup. Previous research has confirmed that this form of contact is an effective tool for reducing prejudice and improving attitudes toward discriminated groups (e.g., Igartua; Wojcieszak; Kim, 2019; Moyer-Gusé; Dale; Ortiz, 2019). Thus, it would seem that the exposure to narratives featuring members of the outgroup facilitates the reduction of prejudice toward this group, which interesting since, sometimes, there is no opportunity to have a direct intergroup contact in the immediate social network (Wojcieszak; Kim; Igartua, 2020). In addition, it offers a non-threatening context, thus avoiding the discomfort or unease that sometimes arises from direct contact with people who are part of stigmatized groups (Chung; Slater, 2013).

Likewise, numerous investigations have ascertained the effectiveness of exposure to written narratives, feature films or television series in reducing the stigma toward discriminated groups (Igartua; Frutos, 2017; Igartua et al., 2017; Igartua et al., 2018; Müller, 2009). This field of study is called narrative persuasion and is based on the use of narratives to induce changes in beliefs, attitudes and behaviors (Green; Brock, 2000; Igartua, 2020; Igartua; Barrios, 2012). A narrative is a representation of events in which characters intervene and where the action is delimited in a specific space and time 
(Kreuter et al., 2007). In this context, narrative interventions have been shown to be an effective strategy for changing attitudes ( $r=.19)$, beliefs ( $r=.17)$, behavioral intent $(r=.17)$, and behaviors $(r=.23)$ (Braddock; Dillard, 2016).

Within this framework, different theoretical models have been developed with the aim of explaining how the impact of narrative messages is produced. The main ones are the Transportation-Imagery Model (Green; Brock, 2002), the Extended Elaboration Likelihood Model (Slater; Rouner, 2002), and the Entertainment Overcoming Resistance Model (Moyer-Gusé, 2008); these models suggest that identification with the characters and narrative transportation are two important processes through which narratives produce their persuasive impact. These processes are relevant because they reduce resistance to the attitudinal proposal of the message, inhibiting the processes of counterarguing and reactance (Bilandzic; Busselle, 2013).

Identification with the characters could be defined as the feeling of becoming the character or temporarily assuming their identity and goals (Cohen, 2001; Igartua; Barrios, 2012). Narrative transportation is a process that produces a psychological state of immersion in the narrative (Green; Brock, 2000). Counterarguing becomes apparent when negative cognitive responses are generated toward the persuasive content of the message (Slater; Rouner, 2002), and reactance is a second process of resistance to the persuasive attempt that is triggered when the individual considers that their freedom is being threatened (Brehm, 1966).

Since identification and transportation facilitate persuasion, it is important to know how both aspects can be enhanced, as activating these processes would indirectly strengthen the persuasive impact of the narrative message (De-Graaf; Sanders; Hoeken, 2016). This research delves into the study of two narrative elements that could enhance identification and transportation: the similarity between the character and the audience, and the narrative voice used in the narration.

\section{Similarity in terms of social identity and narrative voice}

Similarity occurs when the person exposed to a narrative message shares certain characteristics with the protagonist. Previous research has revealed that it is an element that can enhance identification and transportation, although the empirical evidence is inconsistent (Cohen; Weimann-Saks; Mazor-Tregerman, 2018; Kaufman; Libby, 2012; Tukachinsky, 2014).

A limitation of previous research is the fact that it has focused on the effects of demographic similarity, which is based on objective aspects such as gender or age (De-Graaf et al., 2016). Nevertheless, similarity is an aspect that can also be based on more subjective traits such as attitudes, beliefs, values, personality traits, tastes, or interests. This study explores the possibility of strengthening the effect of similarity by manipulating more subjective aspects of it; therefore, the effects of similarity in terms of social identity are tested (Igartua et al., 2019).

From the perspective of social identity theory (Tajfel, 1982), a social group consists of a set of people who perceive themselves as belonging to that group and is based on a series of shared attributes that define the group and distinguish it from other groups. It also postulates that persons belonging to a certain group (ingroup) show a tendency to favor members of the same group (ingroup favoritism), and to discriminate against persons belonging to another group (outgroup discrimination). However, in an intergroup context, it is also possible for an outgroup member to be valued positively if they share some of the typical attributes of the ingroup, i.e. if similarity based on social identity is increased.

This study aims to determine whether the fact that the protagonist of the narration presents himself as an immigrant who shares some attitudinal, psychological and behavioral characteristics typical of the ingroup (high similarity) will lead to a greater identification and narrative transportation (and indirectly a reduction in counterarguing and reactance), than if the immigrant character presents attitudinal, psychological and behavioral characteristics different from those of the ingroup and more related to his original group and country of origin (low similarity).

The main challenge is to generate identification with an immigrant character, since previous research has highlighted the difficulty of inducing identification with stigmatized characters (Chung; Slater, 2013; Igartua; Frutos, 2017). For this reason, the strategy is to combine the effect of similarity with another independent variable in order to increase its effect on character identification and narrative transportation. In this respect, previous investigations have shown that it is possible to increase the effect of similarity on identification and transportation under certain specific conditions. For example, Kaufman \& Libby (2012) observed that the similarity between the character and the audience induced greater identification when the first-person narrative voice was used to tell the story. The present study aims to further deepen this line and explore whether the first-person narrative voice could be a specific condition under which similarity would increase its effect on identification and transportation.

The narrative voice is defined as the perspective from which the story is told (Chen; Bell; Taylor, 2017). The most commonly used strategies are the first-person narrative voice, in which the story is told by the main character using first-person pronouns ("I"), and the third-person narrative voice, in which the story is told by an omniscient narrator who is not part of the story and who refers to the main character either by his first name ("Nasser", in this case), or by using third-person pronouns ("he"). Previous research, mostly in the field of health communication (De-Graaf et al., 2016), suggests that the 
first-person narrative voice has greater persuasive potential (Chen et al., 2017; Igartua; Rodríguez-Contreras, 2020; Nan et al., 2015). However, there is no evidence in the field of prejudice reduction, which is the focus of our work.

\section{Audiovisual narratives}

In the area of narrative persuasion, it is important to know if the modality of presentation of the message conditions the processes of reception and attitudinal impact. The meta-analysis carried out by Tukachinsky (2014) showed that written narratives induced greater narrative transportation than audiovisual narratives. However, in terms of identification, the differences between written and audiovisual narratives were not significant. Nevertheless, it has also been observed that the audiovisual format (as opposed to the written one) increases the involvement with the message (Walter et al., 2017).

Despite these results, most researchers use written narratives as an experimental stimulus (Dahlstrom et al., 2017). This preference is due to the fact that written narratives are easier to manipulate experimentally than audiovisual narratives, but this represents an important limitation for the field of study, since people are not exposed exclusively to media content in written format.

Moreover, when researchers opt for the use of audiovisual narratives, they make use of existing films or television programs, without experimental manipulation; therefore, the videos may differ in other dimensions, in addition to the independent variables, and these potential differences may explain, at least in part, the results obtained (Vezzali et al., 2019).

The present research tries to overcome these limitations by producing the audiovisual narrative message in its entirety and manipulating the independent variables through audiovisual resources. The stimulus used is a short story in the form of a testimonial, in which the protagonist relates his experience and seeks to influence the attitudes and beliefs of the audience (Walter; Cohen, 2019). This narrative format is widely used in health communication campaigns (for example, in the Tips from Former Smokers campaign developed in the United States by the Centers for Disease Control and Prevention) and also by immigrant support agencies (for instance, $h$ ttps://iamamigrant.org) and its potential may be greater than that of other more elaborate narrative formats, since it can be easily shared through social networks. Furthermore, testimonial messages offer a living example, a case story, and for that reason have been observed to be more effective for the development of campaigns, compared to other non-narrative formats that are based on the delivery of statistical evidence (Braverman, 2008).

\section{Objectives and hypotheses}

Firstly, this research aims to contrast the combined effect of similarity in terms of social identity and first-person narrative voice. Thus, it is hypothesized $(\mathrm{H} 1)$ that the audiovisual narration featuring an immigrant protagonist who is similar to the audience in terms of social identity and narrated in the first-person will induce the highest levels of identification with the characters $(\mathrm{H} 1 \mathrm{a})$ and narrative transportation $(\mathrm{H} 2 \mathrm{~b})$.

However, it can also be argued that similarity and narrative voice have independent effects on the reception processes under consideration. Thus, a second objective is to contrast the indirect effects of similarity in terms of social identity as well as the effects of the first-person narrative voice on the dependent variables (intention to share the message, feelings toward UAMs, intention of contact with UAMs and intention of collaborating with an NGO that supports immigrants), through identification with the characters and narrative transportation (primary mediators), and counterarguing and reactance (secondary mediators).

Secondly, it is postulated $(\mathrm{H} 2)$, that the audiovisual narrative featuring an immigrant protagonist who is similar to the audience in terms of social identity will have an indirect effect on the intention to share the message, the feelings toward UAMs, the intention of contact with UAMs and the intention of collaborating with an NGO that supports immigrants, which will be mediated by the identification with the characters $(\mathrm{H} 2 \mathrm{a})$ and narrative transportation ( $\mathrm{H} 2 \mathrm{~b})$ (primary mediators), and counterarguing and reactance (secondary mediators).

Thirdly, it is hypothesized (H3), that the audiovisual narrative told in the first-person will have an indirect effect on the intention to share the message, the feelings toward UAMs, the intention of contact with UAMs and the intention of collaborating with an NGO that supports immigrants, which will be mediated by the identification with the characters (H3a) and narrative transportation (H3b) (primary mediators), and counterarguing and reactance (secondary mediators).

\section{Method}

\subsection{Design and participants}

To test these predictions, an online experiment was designed and distributed through the Qualtrics platform. In order to estimate the required sample size for the experimental study, a power analysis was performed with the statistical software G*Power (Faul et al., 2007). Based on the meta-analysis review carried out by Braddock \& Dillard (2016) and assuming an effect size of .17, an $\alpha$ value of .05, a power of .80, and a four-group between-subjects design, G*Power program indicated that a sample size of 384 participants would be necessary. For this reason, the study was designed to access a sample of this size or slightly larger. To carry out the experiment, a convenience sample was accessed by applying a snowball sampling on the university community, a widely used practice for hypothesis testing in the Communication research (Basil, 1996; Hayes, 2005; Shapiro, 2002). 
As said before, the experimental study was designed through the Qualtrics online platform and the questionnaire was distributed by sending a link that gave access to it. The access to the sample was carried out through social networks, email distribution lists and by contacting directors of research groups from various Spanish universities who were kind enough to spread the questionnaire among the members of their groups. All the participants voluntarily agreed to participate in the research through the informed consent that was shown at the beginning of the questionnaire and in which they were provided general information about the experiment. The fieldwork was carried out between February 4 and March 9, 2020 and to select the participants, the first part of the online questionnaire included three screening questions:

"In which country were you born?",

"In which country was your father born?", and

"In what country was your mother born?".

Only people of Spanish origin and with Spanish parents participated in the study.

A $2 \times 2$ factorial design of independent measures was used, where the similarity in terms of social identity (high vs. low) and the narrative voice (first-person $v s$. third-person) were manipulated in the audiovisual testimonial message. Since the field work was done through Qualtrics, this allowed the random assignment of participants to each experimental condition and the implementation of a series of quality controls during the data collection process. For example, the questionnaire could only be completed in a single session, and in order to avoid respondents that finished the survey abnormally fast (which implies that instead of providing quality answers, they chose answers at random to complete the survey quickly) only those participants who took between 8 and 43 minutes to complete the questionnaire ( $M=$ 12.92 minutes, $S D=4.68)$, who took between 73 and 143 seconds to view the narrative $(M=87.96, S D=10.56)$, and who correctly answered a control question included in the final part of the questionnaire, were counted as valid cases.

All materials related to the online experiment (dataset and syntax files, measures, and narrative messages) are available via the Open Science Framework (OSF):

https://osf.io/xrafb/?view_only=1eb1c91b1b9b4f0781bb7d107d982a05

\section{Materials: Experimental manipulations}

The experimental stimulus used was a one-minute video testimonial featuring an unaccompanied foreign minor of Moroccan origin (this character was played by a former ward Moroccan 18-year-old boy, whose features matched the ones of the role). This narrative related Nasser's migratory experience in Spain, alluding to the difficulties encountered and taking as a reference the written narratives used in previous studies (Igartua et al., 2019).

An audiovisual narrative is mainly characterized by the simultaneous transmission of information through two channels: the acoustic and the visual (Chaume, 2004). In the present study, the visual channel was used to carry out the experimental manipulation of similarity in terms of social identity, and the acoustic channel was used to manipulate the narrative voice.

The manipulation of similarity is based on the theory of social identity (Tajfel, 1982), where it is postulated that people identify with those social groups with which they perceive they share a series of common traits. In the context of our work (intergroup relations with people who are stigmatized because of their belonging to another country), the common elements that constitute a distinct social identity are related to language, symbols, or certain traditions. Thus, in order to manipulate similarity in terms of social identity, two versions of the video were designed (high vs. low similarity) that differed from each other in the following elements.

Language. Language has a dual function as an agent of communication and a symbol of national identity (Mar-Molinero, 2001). An example of this can be found in the Spanish context, where language is an essential part of education systems and is promoted by regional governments because of its importance in the construction of identity. For this reason, in the condition of high similarity the protagonist reads comics in Spanish, while in the condition of low similarity the protagonist reads comics written in Arabic.

Symbols. Sport, and more specifically soccer (football) because of its great popularity, plays an important role in the construction of national identities (Llopis-Goig, 2020). Particularly, the national soccer team has a great symbolic load and is an element of identity construction. In fact, the Spanish society is one of the most identified with the national soccer team, only behind Turkey and Germany (Llopis-Goig; Senyuva; Sonntag, 2017). Hence, in the high similarity condition, the protagonist wears a Spanish national soccer team shirt and posters of the Spanish team are visible in his bedroom, while in the low similarity condition, the protagonist wears a Moroccan national soccer team shirt and posters of the Moroccan team can be seen in his bedroom.

Traditions. Traditions are another common element in the context of a nation, and gastronomy plays an important role among them. In this sense, studies in the field of social anthropology highlight the importance of food in the construction of collective identities (Gracia, 2010). Thus, in the condition of high similarity, there is a photo of the protagonist eating a Spanish potato omelette with a friend, while in the condition of low similarity the photo shows the protagonist eating tajin, a typical Moroccan dish. 
On the other hand, audiovisual stories include locutions that complement the images, either through the dialogues between the characters or through a voice-over, a disembodied voice that is not synchronously anchored to a speaker (Stigel, 2001). In this study, the manipulation of the narrative voice is done through a voice-over. Thus, in the condition of a first-person narrative voice, the audiovisual story includes a voice-over where the protagonist himself tells his story in the first-person ("My name is Nasser and I am 17 years old..."). Whereas, in the condition of a third-person narrative voice, the voice-over belongs to an omniscient narrator who tells the story in the third-person ("This is Nasser and he is $17 . .$. ").

\section{Measures}

The questionnaire consisted of a pre-test measure, which included questions to determine the origin of the participants, socio-demographics (sex and age), ideology (political self-positioning, from $0=$ left, to $10=$ right, $M=3.31, S D=2.38$ ) and perception of the immigration as a problem that affects Spain (from $1=$ very unimportant, to $5=$ very important, $M=3.42, S D=1.14)$, and a post-test measure that was provided immediately after viewing the video and included the following variables.

\subsection{Check variables for experimental manipulation and mediating variables}

Perceived similarity. To test the experimental manipulation, a scale composed of 6 items was used (e.g., "Nasser has many things in common with the Spanish"; from 1= strongly agree, to 7= strongly disagree). The 6 items were combined to create an index $(\alpha=.79, M=5.23, S D=1.03)$.

Identification with the protagonist. The scale developed by Igartua \& Barrios (2012), composed of 11 items (e.g., "I have felt emotionally involved with Nasser's feelings"; from $1=$ nothing, to $5=a$ lot), was used. An index was constructed by averaging the 11 items $(\alpha=.90, M=3.35, S D=0.74)$.

Narrative transportation. The Transportation Scale-Short Form, developed by Appel et al., (2015), was used, consisting of 5 items (e.g., "I could imagine myself in the situations described in the video"; from $1=$ strongly disagree, to $7=$ strongly agree). The 5 items were combined to create a narrative transportation index ( $\alpha=.78, M=4.89, S D=1.09)$.

Counterarguing. A scale created from the studies of Moyer-Gusé \& Nabi (2010) and Igartua \& Vega-Casanova (2016) was used, consisting of 3 items (e.g., "While watching the video, I thought I disagreed with some of the things said by Nasser"; from 1 = strongly disagree, to $7=$ strongly agree). An index was constructed by averaging the 3 items ( $\alpha=.74$, $M=2.53, S D=1.22$.

Reactance. It was measured with the scale developed by Shen (2015), composed of 4 items (e.g., "The message was trying to manipulate me"; from 1 = strongly in disagreement, to 7 = strongly in agreement). The 4 items were combined to create an index $(\alpha=.88, M=1.93, S D=1.15)$.

\subsection{Dependent variables}

Intention to share the message. It was evaluated with the scale developed by Barbour, Doshi, \& Hernández (2016), composed of 6 items (e.g., "I would be willing to share this information with others"; from $1=$ strongly disagree, to $7=$ strongly agree). The 6 items that measured the intention to share the story through social networks were combined into an index $(\alpha=.93, M=4.69, S D=1.41)$.

Thermometer of feelings toward UAMs. A scale was used (Wojcieszak; Garrett, 2018) in which participants indicated their feelings toward the UAMs (from $0=$ very cold feelings, to $100=$ very warm feelings; $M=68.43, S D=25.10$ ).

Intention of contact with UAMs. It was measured using a scale developed from the work of Cameron et al. (2006) y Vezzali et al. (2014), composed of 6 items (e.g., "In general, when I reflect on the situation of the UAMs in Spain, I think I would like to talk to them"; from 1 = strongly disagree, to $7=$ strongly agree). The 6 items were combined to create an index $(\alpha=.90, M=5.49, S D=1.12)$.

Intention to collaborate with an NGO that provides support to immigrants. It was evaluated using a scale created from the work of Murrar \& Brauer (2018), composed of 4 items (e.g., "I would be willing to donate money to an NGO to fund campaigns against racism and xenophobia"; from 1 = strongly disagree, to 7 = strongly agree). The 4 items were combined in an index $(\alpha=.88, M=3.98, S D=1.49)$.

\section{Results}

\subsection{Preliminary analyses}

The random assignment to the four experimental conditions was successful. There were no statistically significant differences among the experimental conditions in sociodemographic terms: $g$ ender $\left(\chi^{2}(3, N=500)=4.24, p=.236\right)$, age $(F(3,496)=.528, p=.663)$; the ideology $(F(3,496)=.937, p=.422)$; or the perception of the immigration as a problem $(F(3,496)=.250, p=.861)$. Moreover, the manipulation of similarity in terms of social identity also proved effective. Through a Student t-test of independent samples, it was observed that the perceived similarity was higher among the participants in the high similarity condition in terms of social identity $(M=5.50, S D=0.97)$ than among the participants in the low similarity condition $(M=4.97, S D=1.02 ; t(498)=-6.00, p=.000)$. Finally, to check that the mediating processes showed convergent correlations with the proposed hypotheses (for example, between identification and narrative 
transportation with counterarguing and reactance), the correlations between the mediating variables were analyzed. In addition, it was also confirmed that the mediating processes showed statistically significant relationships with the dependent variables. These results justify the proposed mediation model (Table 1).

Table 1. Correlations between mediating and dependent variables

\begin{tabular}{|c|c|c|c|c|c|c|c|c|c|}
\hline & & 1 & 2 & 3 & 4 & 5 & 6 & 7 & 8 \\
\hline 1 & Identification & - & & & & & & & \\
\hline 2 & Narrative transportation & $.79 * * *$ & - & & & & & & \\
\hline 3 & Counterarguing & $-.30^{* * * *}$ & $-.23^{* * *}$ & - & & & & & \\
\hline 4 & Reactance & $-.21^{* * *}$ & $-.19 * * *$ & $.44^{* * *}$ & - & & & & \\
\hline 5 & Intention to share the message & $.48^{* * *}$ & $.52^{* * *}$ & $-.34^{* * *}$ & $-.38^{* * *}$ & - & & & \\
\hline 6 & Feelings toward UAMs & $.49 * * *$ & $.45^{* * *}$ & $-.31^{* * *}$ & $-.27^{* * *}$ & $.44 * * *$ & - & & \\
\hline 7 & Intention of contact UAMs & $.47^{* * *}$ & $.42 * * *$ & $-.37^{* * *}$ & $-.37^{* * *}$ & $.51^{* * *}$ & $.72 * * *$ & - & \\
\hline \multirow[t]{3}{*}{8} & Intention to collaborate NGO & $.36^{* * *}$ & $.40^{* * *}$ & $-.18^{* * *}$ & $-.24^{* * *}$ & $.49^{* * *}$ & $.46^{* * *}$ & $.46^{* * *}$ & - \\
\hline & Mean & 3.35 & 4.89 & 2.53 & 1.93 & 4.69 & 68.43 & 5.49 & 3.98 \\
\hline & Standard deviation & 0.74 & 1.09 & 1.22 & 1.15 & 1.41 & 24.10 & 1.12 & 1.49 \\
\hline
\end{tabular}

Note. $N=500$. In all variables, a higher score reflects a greater intensity of the process considered, from $1=l o w$, to $7=h i g h$ (except in the Identification scale with a theoretical range from $1=l o w$, to $5=$ high; and in Feelings toward UAMs with a range from $0=$ very cold feelings, to $100=$ very warm feelings). $+p<.10, * * p<.01, * * * p<.001$.

\subsection{Effect of similarity and narrative voice on reception processes (H1)}

$\mathrm{H} 1$ postulated an interaction effect between similarity in terms of social identity and narrative voice on character identification ( $\mathrm{H} 1 \mathrm{a})$ and narrative transportation $(\mathrm{H} 1 \mathrm{~b})$. To test this effect, two analyses of variance (Anova) were carried out.

The results showed that there were no statistically significant interaction effects between similarity and narrative voice on protagonist identification $\left(F(1,496)=.292, p=.589, \eta_{p}^{2}=.001\right)$, nor on narrative transportation $(F(1,496)=.058, p=$ $\left..809, \eta_{\mathrm{p}}^{2}=.000\right)$, so $\mathrm{H} 1$ was not confirmed.

Nonetheless, main effects of the narrative voice were observed. The message in the first-person increased the identification $\left(F(1,496)=4.83, p=.028, \eta_{p}^{2}=.010\right)$, and the narrative transportation $\left(F(1,496)=6.46, p=.011, \eta_{p}^{2}=.013\right)$. However, similarity in terms of social identity did not influence identification $\left(F(1,496)=.012, p=.914, \eta_{p}^{2}=.000\right)$, nor transportation $\left(F(1,496)=.003, p=.955, \eta_{p}^{2}=.000\right)$.

\subsection{Effects of similarity in terms of social identity (H2)}

The second hypothesis predicted an indirect effect of the similarity in terms of social identity on the intention to share the message, the feelings toward UAMs, the intention of contact with UAMs and the intention of collaborating with an NGO that supports immigrants, all mediated by the identification with the characters (H2b) and narrative transportation ( $\mathrm{H} 2 \mathrm{~b})$ (primary mediators), and counterarguing and reactance (secondary mediators). To analyze the hypothesized mediation model, the Process macro was used to test indirect effects with SPSS (Model 6; Hayes, 2018), including the narrative voice as a covariate.

The results showed that there was no indirect effect of similarity on the dependent variables, given that the independent variable had no statistically significant effect on identification $(B=-.00, S E=.06, p=.915,95 \%$ IC $=-.13, .12)$ or narrative transportation $(B=-.00, S E=.09, p=.955,95 \%$ IC $=-.19$, .18). Consequently, H2 was not confirmed.

O'Keefe (2003) pointed out that the measures used to check experimental manipulations should be included in the mediation analyses, as they could act as relevant underlying processes. Similarly, previous studies have highlighted the effects of perceived similarity on identification and narrative transportation (Chen et al., 2017; Cohen et al., 2018; Cohen; Hershman-Shitrit, 2017; Hoeken; Kolthoff; Sanders, 2016; Ooms; Hoeks; Jansen, 2019).Therefore, a second model of serial mediation (Model 6, Hayes, 2018) was carried out to examine the indirect effect of similarity on dependent variables through perceived similarity (primary mediator), identification and transportation (secondary mediators), and counterarguing and reactance (tertiary mediators), including the narrative voice as a covariate (Figure 1 and Table 2).

Thus, it was observed that similarity in terms of social identity increased perceived similarity, which in turn increased identification with the protagonist of the story. In addition, this increased identification reduced counterarguing and reactance, which was ultimately associated with a greater intention to share the message, more positive feelings toward 
UAMs, greater intention of contact with UAMs and greater intention to collaborate with an NGO supporting immigrants (although in this last case no significant indirect effect through counterarguing was observed).

Regarding the role of narrative transportation, it was observed that perceived similarity acted as a mediating variable for the effect of similarity in terms of social identity on narrative transportation, which at the same time reduced counterarguing and reactance. This reduction of counterarguing and reactance (thanks to the increase in narrative transportation) was associated with a greater intention to share the message, more positive feelings toward UAMs, a greater intention to contact UAMs and a greater intention to collaborate with an NGO providing support to immigrants.

(a) Secondary mediator: identification

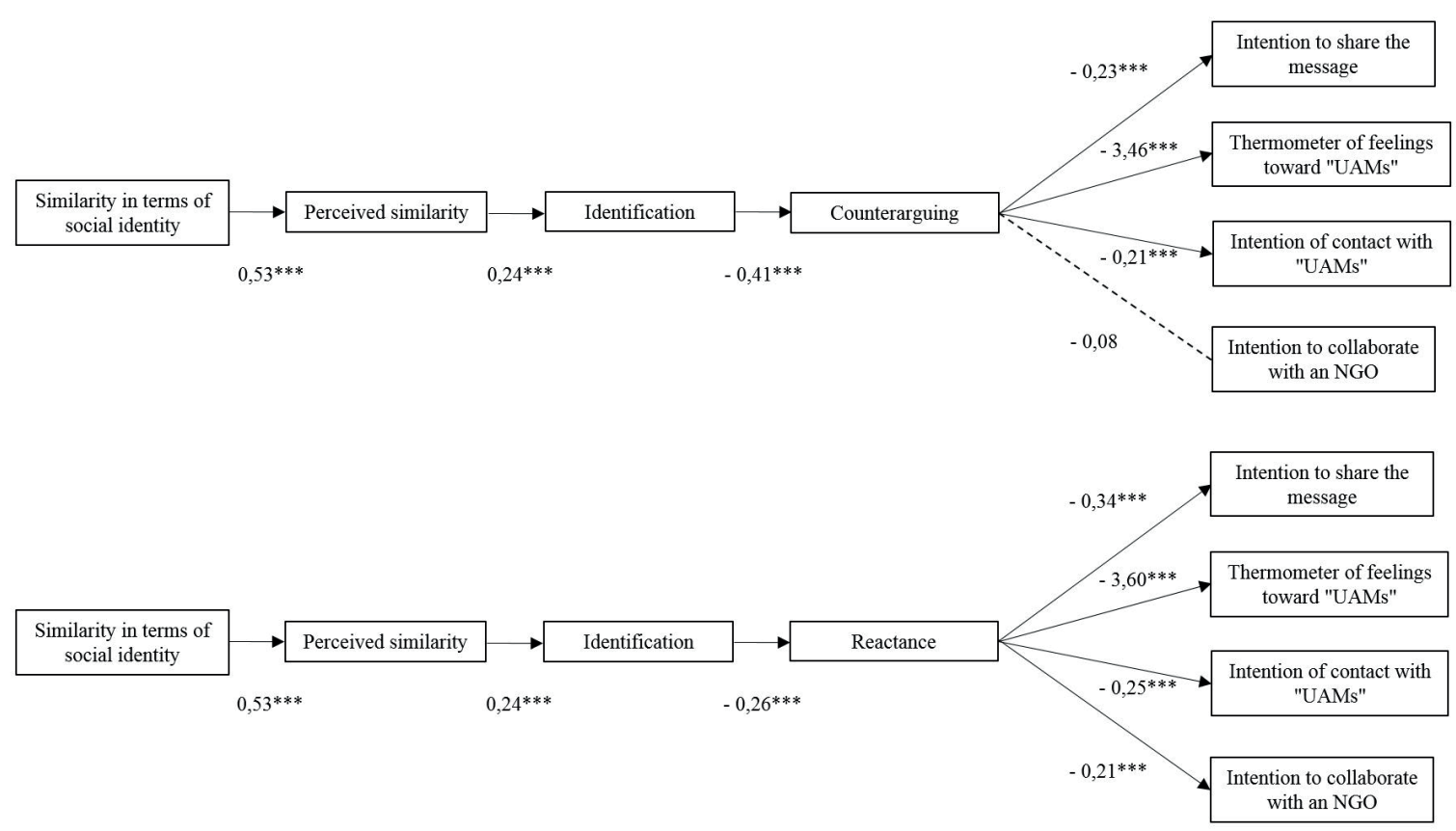

(b) Secondary mediator: transportation

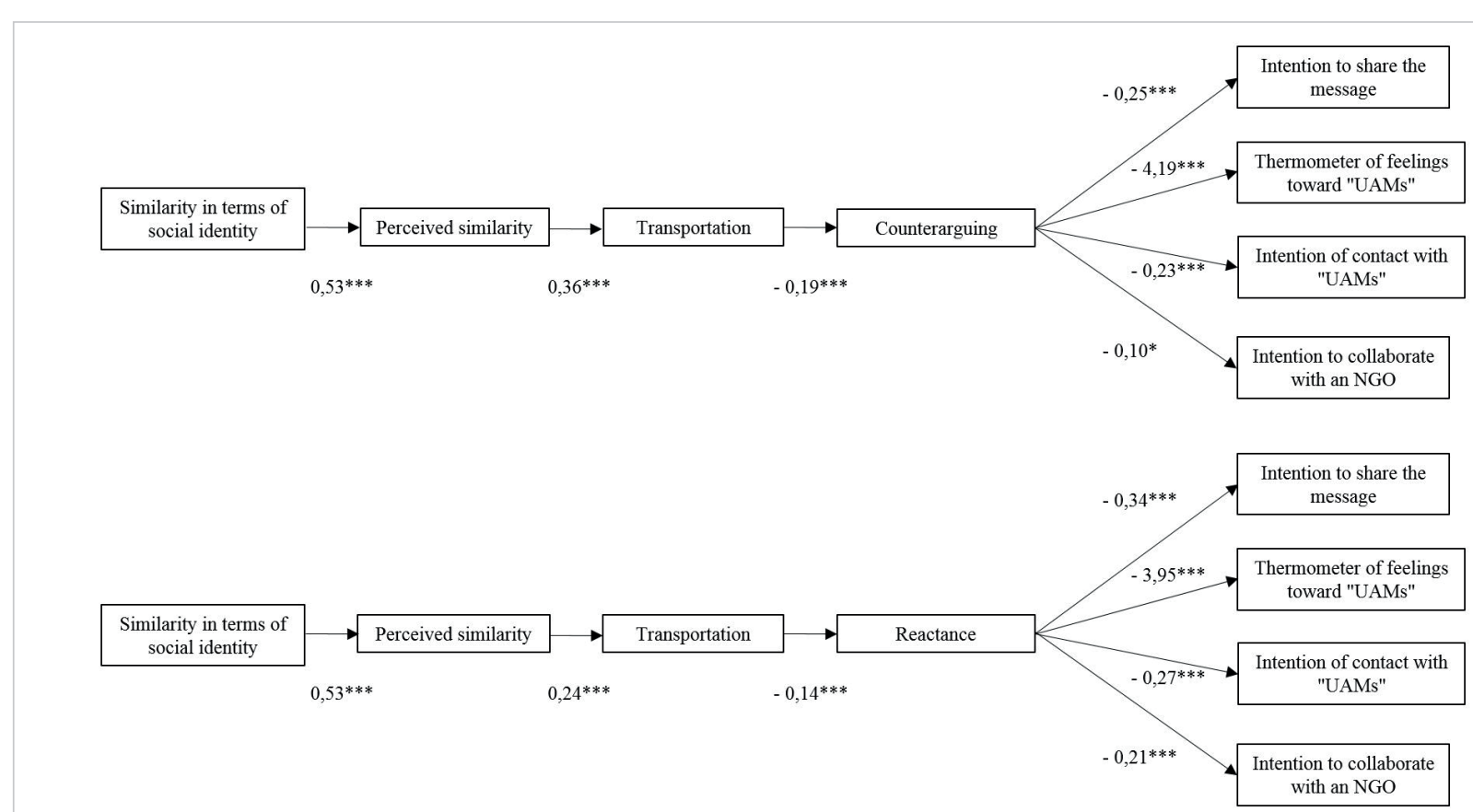

Figure 1. Mediation analyses: indirect effects of similarity $(\mathrm{H} 2)$

Note. The figures show the non-standardized regression coefficients $(B)$. The dashed line represents non-significant coefficients. $+p<.10, * p<.05$, $* * p<.01, * * * p<.001$. 
Table 2. Indirect effects of similarity in terms of social identity on dependent variables

\begin{tabular}{|c|c|c|c|}
\hline Indirect effects & Effect & Boot SE & Boot $95 \% \mathrm{Cl}$ \\
\hline $\begin{array}{l}\text { Social identity similarity } \rightarrow \text { Perceived similarity } \rightarrow \text { Identification } \\
\rightarrow \text { Counterarguing } \rightarrow \text { Intention to share the message }\end{array}$ & .0125 & .0047 & {$[.0054, .0233]$} \\
\hline $\begin{array}{l}\text { Social identity similarity } \rightarrow \text { Perceived similarity } \rightarrow \text { Identification } \\
\rightarrow \text { Counterarguing } \rightarrow \text { Feelings toward UAMs }\end{array}$ & .1856 & .0761 & {$[.0688, .3666]$} \\
\hline $\begin{array}{l}\text { Social identity similarity } \rightarrow \text { Perceived similarity } \rightarrow \text { Identification } \\
\rightarrow \text { Counterarguing } \rightarrow \text { Intention of contact with UAMs }\end{array}$ & .0113 & .0040 & {$[.0050, .0205]$} \\
\hline $\begin{array}{l}\text { Social identity similarity } \rightarrow \text { Perceived similarity } \rightarrow \text { Identification } \\
\rightarrow \text { Counterarguing } \rightarrow \text { Intention to collaborate with NGO }\end{array}$ & .0045 & .0034 & {$[-.0011, .0125]$} \\
\hline $\begin{array}{l}\text { Social identity similarity } \rightarrow \rightarrow \text { Perceived similarity } \rightarrow \text { Identification } \\
\rightarrow \text { Reactance } \rightarrow \text { Intention to share the message }\end{array}$ & .0116 & .0048 & {$[.0040, .0226]$} \\
\hline $\begin{array}{l}\text { Social identity similarity } \rightarrow \text { Perceived similarity } \rightarrow \text { Identification } \\
\rightarrow \text { Reactance } \rightarrow \text { Feelings toward UAMs }\end{array}$ & .1224 & .0596 & {$[.0342, .2635]$} \\
\hline $\begin{array}{l}\text { Social identity similarity } \rightarrow \text { Perceived similarity } \rightarrow \text { Identification } \\
\rightarrow \text { Reactance } \rightarrow \text { Intention of contact with UAMs }\end{array}$ & .0087 & .0036 & {$[.0029, .0170]$} \\
\hline $\begin{array}{l}\text { Social identity similarity } \rightarrow \text { Perceived similarity } \rightarrow \text { Identification } \\
\rightarrow \text { Reactance } \rightarrow \text { Intention to collaborate with NGO }\end{array}$ & .0074 & .0035 & {$[.0022, .0155]$} \\
\hline $\begin{array}{l}\text { Social identity similarity } \rightarrow \text { Perceived similarity } \rightarrow \text { Transportation } \\
\rightarrow \text { Counterarguing } \rightarrow \text { Intention to share the message }\end{array}$ & .0097 & .0040 & {$[.0035, .0191]$} \\
\hline $\begin{array}{l}\text { Social identity similarity } \rightarrow \text { Perceived similarity } \rightarrow \text { Transportation } \\
\rightarrow \text { Counterarguing } \rightarrow \text { Feelings toward UAMs }\end{array}$ & .1595 & .0685 & {$[.0540, .3209]$} \\
\hline $\begin{array}{l}\text { Social identity similarity } \rightarrow \text { Perceived similarity } \rightarrow \text { Transportation } \\
\rightarrow \text { Counterarguing } \rightarrow \text { Intention of contact with UAMs }\end{array}$ & .0091 & .0037 & {$[.0033, .0179]$} \\
\hline $\begin{array}{l}\text { Social identity similarity } \rightarrow \text { Perceived similarity } \rightarrow \text { Transportation } \\
\rightarrow \text { Counterarguing } \rightarrow \text { Intention to collaborate with NGO }\end{array}$ & .0040 & .0027 & {$[.0001, .0105]$} \\
\hline $\begin{array}{l}\text { Social identity similarity } \rightarrow \text { Perceived similarity } \rightarrow \text { Transportation } \\
\rightarrow \text { Reactance } \rightarrow \text { Intention to share the message }\end{array}$ & .0101 & .0044 & {$[.0027, .0198]$} \\
\hline $\begin{array}{l}\text { Social identity similarity } \rightarrow \text { Perceived similarity } \rightarrow \text { Transportation } \\
\rightarrow \text { Reactance } \rightarrow \text { Feelings toward UAMs }\end{array}$ & .1152 & .0593 & {$[.0246, .2537]$} \\
\hline $\begin{array}{l}\text { Social identity similarity } \rightarrow \text { Perceived similarity } \rightarrow \text { Transportation } \\
\rightarrow \text { Reactance } \rightarrow \text { Intention of contact with UAMs }\end{array}$ & .0079 & .0036 & {$[.0020, .0160]$} \\
\hline $\begin{array}{l}\text { Social identity similarity } \rightarrow \text { Perceived similarity } \rightarrow \text { Transportation } \\
\rightarrow \text { Reactance } \rightarrow \text { Intention to collaborate with NGO }\end{array}$ & .0064 & .0031 & {$[.0015, .0136]$} \\
\hline
\end{tabular}

Note. An indirect effect is considered to be statistically significant if the established confidence interval (95\% $\mathrm{Cl})$ does not include the value 0 (Hayes, 2018). Statistically significant indirect effects are marked in bold.

\subsection{Effects of the narrative voice (H3)}

The third hypothesis postulated an indirect effect of the narrative voice on dependent variables, mediated by the identification with the protagonist $(\mathrm{H} 3 \mathrm{a})$ and the narrative transportation $(\mathrm{H} 3 \mathrm{~b})$ (primary mediators), and the counterarguing and reactance (secondary mediators). The serial mediation model was tested in the same way (Model 6, Hayes, 2018), including similarity in terms of social identity as a covariate.

It was observed that the narrative voice in the first-person (versus third-person) increased identification with the protagonist of the story, which in turn reduced counterarguing and reactance. In addition, the reduction of counterarguing and reactance (as a result of increased identification) was associated with a greater intention to share the message, more positive feelings toward UAMs, greater intention of contact with UAMs and greater intention to collaborate with an NGO providing support to immigrants, although in this last case a significant indirect effect was only found through reactance, which is a partial support of $\mathrm{H} 3 \mathrm{a}$.

On the other hand, the first-person narrative voice also increased narrative transportation, which at the same time reduced counterarguing and reactance. Furthermore, the reduction of counterarguing and reactance (thanks to the increase in narrative transportation) was associated with a greater intention to share the message, more positive feelings toward the UAMs, a greater intention to contact UAMs and a greater intention to collaborate with an NGO providing support to immigrants; therefore, the $\mathrm{H} 3 \mathrm{~b}$ was confirmed (Figure 2 and Table 3 ).

The first-person narrative voice increased identification and transportation, which in turn reduced counterarguing and reactance 
(a) Primary mediator: identification

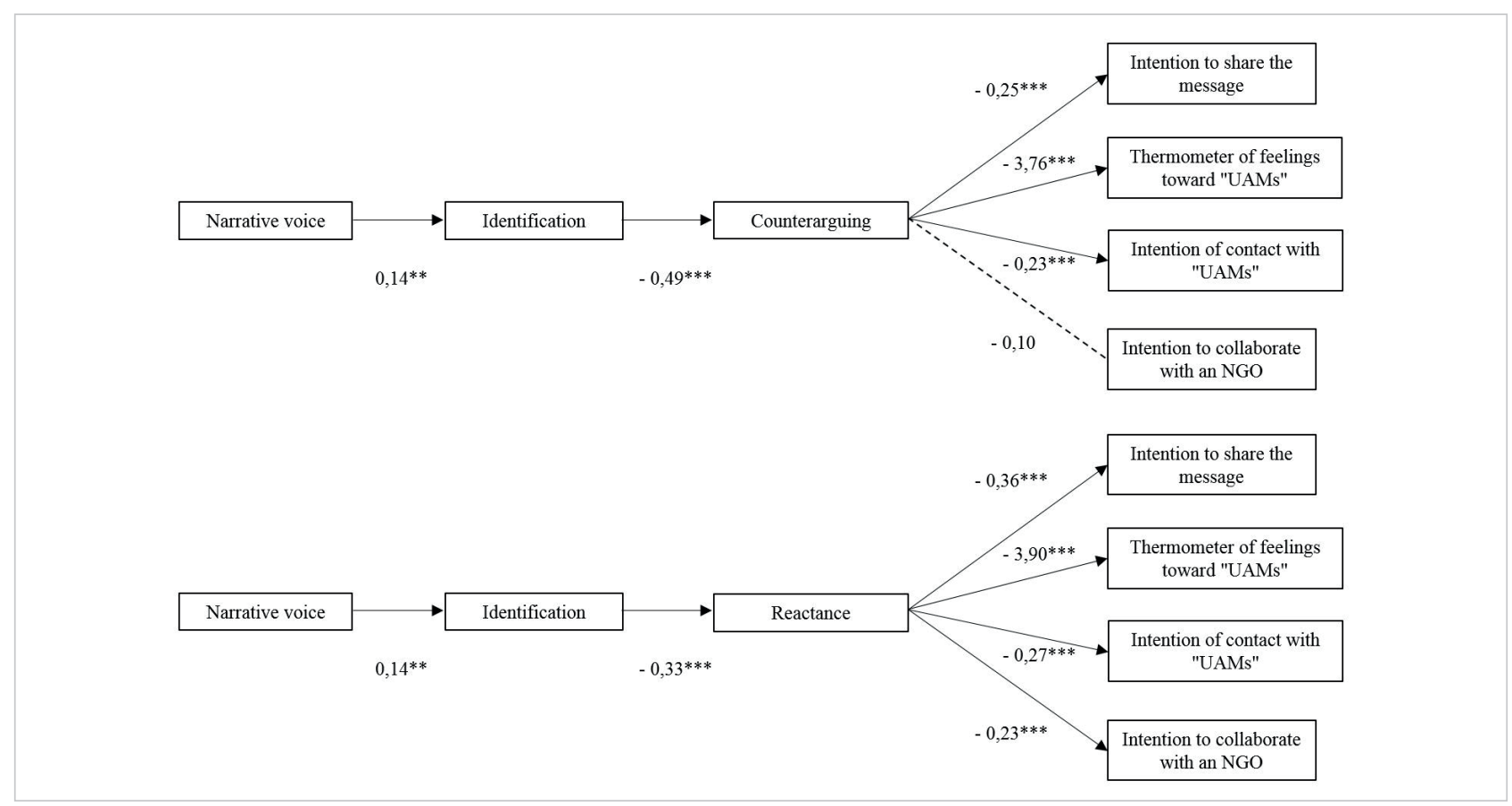

(b) Primary mediator: transportation

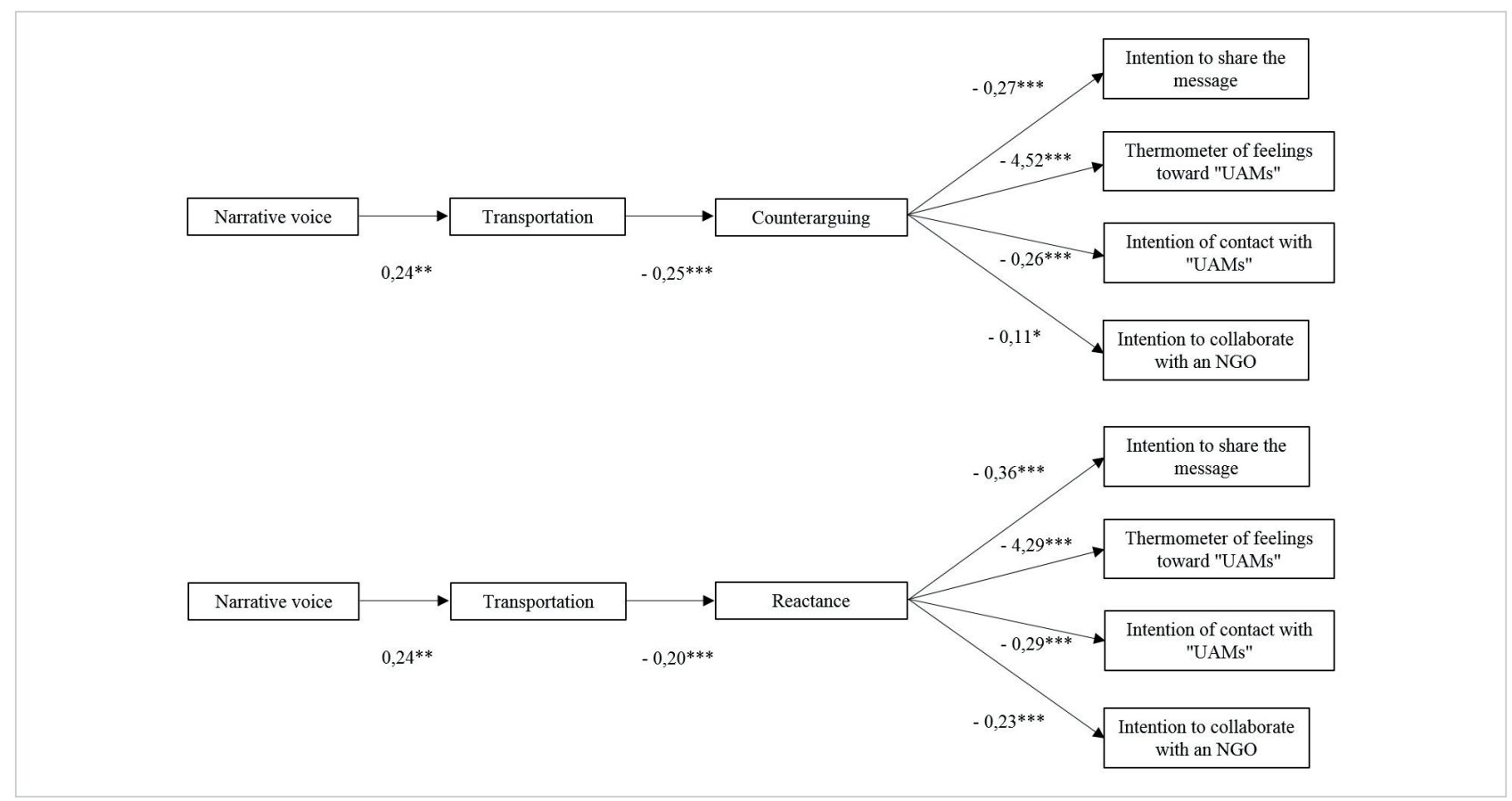

Figure 2. Mediation analyses: indirect effects of the narrative voice $(\mathrm{H} 3)$.

Note. The Figures show the non-standardized regression coefficients $(B)$. The dashed line represents non-significant coefficients. $+p<.10, * p<.05$, $* * p<.01, * * * p<.001$. 
Table 3. Indirect effects of narrative voice on dependent variables

\begin{tabular}{|c|c|c|c|}
\hline Indirect effects & Effect & Boot SE & Boot $95 \% \mathrm{Cl}$ \\
\hline $\begin{array}{l}\text { Narrative voice } \rightarrow \text { Identification } \rightarrow \\
\text { Counterarguing } \rightarrow \text { Intention to share the message }\end{array}$ & .0183 & .0093 & {$[.0018, .0387]$} \\
\hline $\begin{array}{l}\text { Narrative voice } \rightarrow \text { Identification } \rightarrow \\
\text { Counterarguing } \rightarrow \text { Feelings toward UAMs }\end{array}$ & .2694 & .1459 & {$[.0241, .5926]$} \\
\hline $\begin{array}{l}\text { Narrative voice } \rightarrow \text { Identification } \rightarrow \\
\text { Counterarguing } \rightarrow \text { Intention of contact with UAMs }\end{array}$ & .0167 & .0084 & {$[.0016, .0353]$} \\
\hline $\begin{array}{l}\text { Narrative voice } \rightarrow \text { Identification } \rightarrow \\
\text { Counterarguing } \rightarrow \text { Intention to collaborate NGO }\end{array}$ & .0072 & .0055 & {$[-.0010, .0201]$} \\
\hline $\begin{array}{l}\text { Narrative voice } \rightarrow \text { Identification } \rightarrow \text { Reactance } \rightarrow \\
\text { Intention to share the message }\end{array}$ & .0178 & .0091 & {$[.0017, .0370]$} \\
\hline $\begin{array}{l}\text { Narrative voice } \rightarrow \text { Identification } \rightarrow \text { Reactance } \rightarrow \\
\text { Feelings toward UAMs }\end{array}$ & .1915 & .1074 & {$[.0166, .4364]$} \\
\hline $\begin{array}{l}\text { Narrative voice } \rightarrow \text { Identification } \rightarrow \text { Reactance } \rightarrow \\
\text { Intention of contact with UAMs }\end{array}$ & .0136 & .0071 & {$[.0013, .0286]$} \\
\hline $\begin{array}{l}\text { Narrative voice } \rightarrow \text { Identification } \rightarrow \text { Reactance } \rightarrow \\
\text { Intention to collaborate with NGO }\end{array}$ & .0113 & .0064 & {$[.0009, .0256]$} \\
\hline $\begin{array}{l}\text { Narrative voice } \rightarrow \text { Transportation } \rightarrow \\
\text { Counterarguing } \rightarrow \text { Intention to share the message }\end{array}$ & .0176 & .0081 & {$[.0039, .0352]$} \\
\hline $\begin{array}{l}\text { Narrative voice } \rightarrow \text { Transportation } \rightarrow \\
\text { Counterarguing } \rightarrow \text { Feelings toward UAMs }\end{array}$ & .2895 & .1366 & {$[.0620, .5984]$} \\
\hline $\begin{array}{l}\text { Narrative voice } \rightarrow \text { Transportation } \rightarrow \\
\text { Counterarguing } \rightarrow \text { Intention of contact with UAMs }\end{array}$ & .0171 & .0078 & {$[.0037, .0349]$} \\
\hline $\begin{array}{l}\text { Narrative voice } \rightarrow \text { Transportation } \rightarrow \\
\text { Counterarguing } \rightarrow \text { Intention to collaborate NGO }\end{array}$ & .0076 & .0049 & {$[.0004, .0190]$} \\
\hline $\begin{array}{l}\text { Narrative voice } \rightarrow \text { Transportation } \rightarrow \text { Reactance } \rightarrow \\
\text { Intention to share the message }\end{array}$ & .0184 & .0083 & {$[.0037, .0364]$} \\
\hline $\begin{array}{l}\text { Narrative voice } \rightarrow \text { Transportation } \rightarrow \text { Reactance } \rightarrow \\
\text { Feelings toward UAMs }\end{array}$ & .2168 & .1062 & {$[.0421, .4489]$} \\
\hline $\begin{array}{l}\text { Narrative voice } \rightarrow \text { Transportation } \rightarrow \text { Reactance } \rightarrow \\
\text { Intention of contact with UAMs }\end{array}$ & .0150 & .0070 & {$[.0031, .0301]$} \\
\hline $\begin{array}{l}\text { Narrative voice } \rightarrow \text { Transportation } \rightarrow \text { Reactance } \rightarrow \\
\text { Intention to collaborate with NGO }\end{array}$ & .0117 & .0060 & {$[.0021, .0252]$} \\
\hline
\end{tabular}

Note. An indirect effect is considered to be statistically significant if the established confidence interval $(95 \% \mathrm{Cl})$ does not include the value 0 (Hayes, 2018). Statistically significant indirect effects are marked in bold.

\section{Discussion}

This work focuses on the reduction of prejudice toward stigmatized immigrants (specifically unaccompanied minors or UAMs) through audiovisual testimonial messages. It also highlights the importance of two elements related to the construction of the narrative message in the activation of mediating processes that facilitate persuasion: the similarity between the character and the audience, and the narrative voice.

In this sense, the effects of a type of similarity based on subjective features such as similarity in terms of social identity were tested (Igartua et al., 2019), since, to date, research has focused mainly on the study of demographic similarity, and the empirical evidence of its effect on identification and transportation is inconsistent (Tukachinsky, 2014). The results revealed that similarity in terms of social identity had no statistically significant effect on identification or transportation. Neither was it observed a combined effect of similarity and narrative voice on identification or transportation, so $\mathrm{H} 1$ could not be confirmed.

Nevertheless, and in convergence with previous studies, it was observed that perceived similarity acted as a process mediating the effect of similarity on identification and transportation (Chen et al., 2017; Cohen; Hershman-Shitrit, 2017; Hoeken et al., 2016; Ooms et al., 2019). These results highlight that similarity between the character and the audience can be an important element for enhancing the persuasive effect of a message, as long as the audience recognizes the shared features and perceives the character as similar (Kim, 2019).

In addition, mediation analyses revealed that the increase in identification and transportation (explained by the increase in perceived similarity) reduced counterarguing and reactance, which in turn was associated with greater intention to share the message, more favorable attitudes toward UAMs (feelings and intention to contact) and greater intention for prosocial behavior (in this case no significant indirect effect was observed through identification and counterarguing). 
As for $\mathrm{H} 3$, it was found that the first-person narrative voice (versus third-person) increased identification and transportation, which in turn reduced counterarguing and reactance; this was ultimately associated with greater intention to share the message, more positive attitudes toward UAMs, and greater intention for prosocial behavior in favor of immigrants (although in this last case no significant indirect effect through identification and counterarguing was observed). These results emphasize the ability of the first-person narrative voice to amplify the effect of the message on the identification with the protagonist (Chen et al., 2017; Igartua; Rodríguez-Contreras, 2020; Nan et al., 2015). Furthermore, and unlike what was found in previous studies (Banjerjee; Greene, 2012; Tukachinsky, 2014), these results show that the first-person narrative voice could also be a relevant resource for increasing narrative transportation, which makes it an important element to be taken into account in the construction of narrative messages.

On the other hand, this study revealed that both identification and narrative transportation reduced counterarguing and reactance, which jointly explained the effect of similarity and narrative voice on dependent variables. These findings converge with theoretical models (Green; Brock, 2002; Slater; Rouner, 2002; Moyer-Gusé, 2008) and underline the importance of these mediating mechanisms in the processes of narrative persuasion, but in a different context such as that of racism and xenophobia prevention.

This study provides various theoretical and practical contributions and highlight the importance of narrative messages in reducing prejudice towards stigmatized groups. In the first place, it was found that it is possible to manipulate similarity by making subjective aspects prominent in the narrative that highlight a shared social identity between the protagonist and the audience (such as tastes, interests or feelings), since similarity in terms of social identity increased perceived similarity. A knowledge that can help audiovisual producers to develop more successful campaigns against racism and xenophobia.

Secondly, it was possible to induce identification with a stigmatized character, which was one of the main challenges since previous research has highlighted the difficulty of triggering identification with this type of characters (Chung; Slater, 2013; Igartua; Frutos, 2017).

Thirdly, the findings of this research represent a significant contribution to the study of the effects of narrative voice. This topic has received scarce attention in narrative persuasion research (De-Graaf et al., 2016), and although previous studies suggest a greater persuasive potential for first-person narratives (De-Graaf et al., 2016), the evidence was not conclusive (Banerjee; Greene, 2012; Chen et al., 2015; 2016; Christy, 2018; Nan et al., 2017; Tukachinsky, 2014). In this sense, the present study has highlighted that the narrative voice is not a merely anecdotal formal resource (Igartua; Rodríguez-Contreras, 2020). On the contrary, it is a narrative feature that indirectly affects variables related to the reduction of prejudice, because first-person messages allow the activation of relevant mechanisms such as identification and narrative transportation.

Likewise, as far as we know, this study represents the first attempt to test a serial mediation model that takes into account four different mechanisms (identification, transportation, counterarguing and reactance) for explaining the reduction of the prejudice toward stigmatized immigrants. Therefore, our study has important implications for this field, since the results allow to understand the role of identification and narrative transportation in the reduction of defensive responses to the message (counterarguing and reactance) which, in turn, leads to the improvement of attitudes.

Additionally, it should be noted that the present research has included alternative dependent variables to the classic ones used in the previous research, which have focused mainly on the use of attitudinal measures related to the content of the narrative. In this sense, this study has shown that the intention to share a message of these characteristics through social media can be stimulated, which already constitutes an indicator of the effectiveness of the communicative intervention (Igartua et al., 2017). Furthermore, taking into account that the audience tends to avoid stories about stigmatized groups (Walter et al., 2017), the fact that the narratives with a favorable message towards immigration come from personal contacts could increase trust in them and, ultimately, its persuasive efficacy (Igartua et al., 2017). Likewise, media campaigns play a vital role in the fundraising activities by NGOs since, in many cases, the audience learns about the needs of others through the media (Cao, 2013). The present study has highlighted that a first-person narrative message featuring an immigrant protagonist who is similar to the audience in terms of social identity, can increase the intention to collaborate with an NGO that supports immigrants. A relevant evidence that could be used by these organizations in the design of media campaigns to encourage donations.

The present study has shown that the manipulation of certain narrative elements related to the construction of the messages can increase the effectiveness of audiovisual messages designed to reduce prejudice towards UAMs in Spain. However, future research should test if these findings could be replicated in other geographical contexts, or if similar results would be obtained with protagonists belonging to other stigmatized groups that produce more anxiety in the audience. For this reason, it would be convenient to verify the effectiveness of this media intervention with other stigmatized groups (e.g., people of other religious beliefs such as Muslims, handicapped, homeless people etc.), and in cultural 
contexts other than Spanish, in order to confirm that the effects of the similarity in terms of social identity and narrative voice are maintained regardless of the stigmatized group and the cultural origin of the audience of the message.

Likewise, narrative messages do not affect all people equally and can produce stronger or weaker effects depending on certain factors (Valkenburg; Peter; Walther, 2016). For this reason, it would be convenient to study to what extent the individual characteristics of the audience (such as certain personality traits or other psychological characteristics), can condition the effect of these narrative elements.

Finally, in this project, self-report measures have been used to evaluate the processes of identification, transportation, counterarguing and reactance, which are taken retrospectively immediately after exposure to stimulus materials. These measures are valid and widely used in Communication research. However, the reception of a narrative message is a dynamic phenomenon, which implies that mediating processes such as identification or transportation fluctuate and undergo changes throughout the exposure to the narrative (Igartua, 2020). For this reason, future research should use these self-report measures in combination with other physiological measures based on neuroimaging techniques (see, Van-Krieken et al., 2017), with the aim of analyzing reception processes during exposure to the stimulus and in a more complete and accurate manner (Igartua, 2020).

A limitation of this study is that a representative sample of the Spanish population was not used, as a snowball-based selection procedure of participants was implemented through social media and university email lists. In this sense, these findings should be tested with representative samples where, predictably, more negative attitudes toward immigrants will be observed, since education is a protective factor against prejudice towards stigmatized groups such as immigrants (Cea-D’Ancona; Valles-Martínez, 2014).

In conclusion, this work improves the understanding of the mechanisms involved in narrative persuasion processes and demonstrates that the manipulation of certain narrative elements (such as the similarity between the character and the audience in terms of social identity and the use of the first-person narrative voice) can increase the effectiveness of messages designed for the prevention of racism and xenophobia.
The results demonstrate that the manipulation of the similarity in terms of social identity and the use of the first-person narrative voice can increase the effectiveness of messages designed for the prevention of racism and xenophobia

\section{Bibliography}

Allport, Gordon-Willard (1954). The nature of prejudice. Reading: Addison-Wesley. ISBN: 9780201001754

Appel, Markus; Gnambs, Timo; Richter, Tobias; Green, Melanie C. (2015). "The transportation scale-short form (TS-SF)". Media psychology, v. 18, n. 2, pp. 243-266.

https://doi.org/10.1080/15213269.2014.987400

Banerjee, Smita C.; Greene, Kathryn (2012). "Role of transportation in the persuasion process: cognitive and affective responses to antidrug narratives". Journal of health communication, v. 17, n. 5, pp. 564-581. https://doi.org/10.1080/10810730.2011.635779

Barbour, Joshua B.; Doshi, Marissa J.; Hernández, Leandra H. (2016). "Telling global public health stories: narrative message design for issues management". Communication research, v. 43, n. 6, pp. 810-843.

https://doi.org/10.1177/0093650215579224

Basil, Michael D. (1996). "Standpoint: The use of student samples in communication research". Journal of broadcasting \& electronic media, v. 40, n. 3, pp. 431-440.

https://doi.org/10.1080/08838159609364364

Bilandzic, Helena; Busselle, Rick (2013). “Narrative persuasion”. In: Dillard, James Price; Shen, Lijiang (Eds.). The SAGE handbook of persuasion: Developments in theory and practice. Thousand Oaks: Sage Publications, pp. 200-219. ISBN: 9781412983136

Braddock, Kurt; Dillard, James-Price (2016). "Meta-analytic evidence for the persuasive effect of narratives on beliefs, attitudes, intentions, and behaviors". Communication monographs, v. 83, n. 4, pp. 446-467.

https://doi.org/10.1080/03637751.2015.1128555

Braverman, Julia (2008). "Testimonials versus informational persuasive messages: the moderating effect of delivery mode and personal involvement". Communication research, v. 35, n. 5, pp. 666-694.

https://doi.org/10.1177/0093650208321785

Brehm, Jack-Williams (1966). A theory of psychological reactance. New York: Academic Press. ISBN: 9780121298500

Cameron, Lindsey; Rutland, Adam; Brown, Rupert; Douch, Rebecca (2006). “Changing children's intergroup attitudes toward refugees: testing different models of extended contact". Child development, v. 77, n. 5, pp. 1208-1219.

https://doi.org/10.1111/j.1467-8624.2006.00929.x 
Cao, Xiaoxia (2013). "The effects of facial close-ups and viewers' sex on empathy and intentions to help people in need". Mass communication and society, v. 16, n. 2, pp. 161-178.

https://doi.org/10.1080/15205436.2012.683928

Cea-D’Ancona, María-Ángeles; Valles-Martínez, Miguel (2014). Evolución del racismo, la xenofobia y otras formas conexas de intolerancia en España (Informe-encuesta 2014). Madrid: Subdirección General de Información Administrativa y Publicaciones. ISBN: 9788484174868

Centro de Investigaciones Sociológicas (2017). Actitudes hacia la inmigración (Estudio № 1519).

http://www.cis.es/cis/opencm/ES/1_encuestas/estudios/ver.jsp?estudio=14367

Chaume, Frederic (2004). Cine y traducción. Madrid: Ediciones Cátedra. ISBN: 9788437621364

Chen, Meng; Bell, Robert A.; Taylor, Laramie D. (2016). "Narrator point of view and persuasion in health narratives: The role of protagonist-reader similarity, identification, and self-referencing". Journal of health communication, v. 21, n. 8, pp. 908-918. https://doi.org/10.1080/10810730.2016.1177147

Chen, Meng; Bell, Robert A.; Taylor, Laramie D. (2017). "Persuasive effects of point of view, protagonist competence, and similarity in a health narrative about type 2 diabetes". Journal of health communication, v. 22, n. 8, pp. $702-712$. https://doi.org/10.1080/10810730.2017.1341568

Chen, Meng; McGlone, Matthew S.; Bell, Robert A. (2015). "Persuasive effects of linguistic agency assignments and point of view in narrative health messages about colon cancer". Journal of health communication, v. 20, n. 8, pp. $977-988$. https://doi.org/10.1080/10810730.2015.1018625

Christy, Katheryn R. (2018). "I, you, or he: Examining the impact of point of view on narrative persuasion". Media psychology, v. 21, n. 4, pp. 700-718.

https://doi.org/10.1080/15213269.2017.1400443

Chung, Adrienne H.; Slater, Michael D. (2013). "Reducing stigma and out-group distinctions through perspective-taking in narratives". Journal of communication, v. 63, n. 5, pp. 894-911.

https://doi.org/10.1111/jcom.12050

Cohen, Jonathan (2001). "Defining identification: a theoretical look at the identification of audiences with media characters". Mass communication \& society, v. 4, n. 3, pp. 245-264.

https://doi.org/10.1207/S15327825MCS0403_01

Cohen, Jonathan; Hershman-Shitrit, Michal (2017). "Mediated relationships with TV characters: the effects of perceived and actual similarity in personality traits". Scientific study of literature, v. 7, n. 1, pp. 109-128.

https://doi.org/10.1075/ssol.7.1.05coh

Cohen, Jonathan; Weimann-Saks, Dana; Mazor-Tregerman, Maya (2018). "Does character similarity increase identification and persuasion?". Media psychology, v. 21, n. 3, pp. 506-528.

https://doi.org/10.1080/15213269.2017.1302344

Dahlstrom, Michael F.; Niederdeppe, Jeff; Gao, Lijing; Zhu, Xiaowen (2017). “Operational and conceptual trends in narrative persuasion research: comparing health- and non-health-related contexts". International journal of communication, v. 11, pp. 4865-4885. https://ijoc.org/index.php/ijoc/article/view/6629/2202

De-Graaf, Anneke; Sanders, José; Hoeken, Hans (2016). “Characteristics of narrative interventions and health effects: a review of the content, form, and context of narratives in health-related narrative persuasion research". Review of communication research, v. 4, pp. 88-131.

https://doi.org/10.12840/issn.2255-4165.2016.04.01.011

EU Commission; EU Parliament (2011). Directive 2011/95/EU of the European Parliament and of the Council on standards for the qualification of third-country nationals or stateless as persons as beneficiaries of international protection, for a uniform status for refugees or for persons eligible fort subsidiary protection, and for the content of the protection granted. https://eur-lex.europa.eu/LexUriServ/LexUriServ.do?uri=OJ:L:2011:337:0009:0026:en:PDF

Faul, Fraz; Erdfelder, Edgar; Lang, Albert-Georg; Buchner, Axel (2007). "G* Power 3: A flexible statistical power analysis program for the social, behavioral, and biomedical sciences". Behavior research methods, v. 39, n. 2, pp. $175-191$. https://doi.org/10.3758/bf03193146

Fuentes-Sánchez, Raquel (2014). "Menores extranjeros no acompañados (MENA)". Revista internacional de trabajo social y bienestar, n. 3, pp. 105-111.

https://revistas.um.es/azarbe/article/view/198431

Gómez-Quintero, Juan-David; Aguerri, Jesús C.; Gimeno-Monterde, Chabier (2021). "Representaciones mediáticas de los menores que migran solos: Los MENA en la prensa española”. Comunicar, v. 29, n. 66, pp. 95-105.

https://doi.org/10.3916/C66-2021-08 
Gracia, Mabel (2010). “Alimentación y cultura en España: una aproximación desde la antropología social”. Physis: Revista de saúde coletiva, v. 20, n. 2, pp. 357-386.

https://doi.org/10.1590/S0103-73312010000200003

Green, Melanie C.; Brock, Timothy C. (2000). "The role of transportation in the persuasiveness of public narratives". Journal of personality and social psychology, v. 79, n. 5, pp. 701-721.

https://doi.org/10.1037/0022-3514.79.5.701

Green, Melanie C.; Brock, Timothy C. (2002). "In the mind's eye: transportation-imagery model of narrative persuasion". In: Green, Melanie C.; Strange, Jeffrey J.; Brock, Timothy C. (eds.). Narrative impact. Social and cognitive foundations. Mahwah: Lawrence Erlbaum Associates, pp. 315-341. ISBN: 080583124 X

Hayes, Andrew F. (2018). Introduction to mediation, moderation, and conditional process analysis: a regression-based approach. New York: Guilford Press. ISBN: 9781462534654

Hoeken, Hans; Kolthoff, Matthijs; Sanders, José (2016). "Story perspective and character similarity as drivers of identification and narrative persuasion". Human communication research, v. 42, n. 2, pp. 292-311.

https://doi.org/10.1111/hcre.12076

Igartua, Juan-José (2020). “Claves metodológicas de la investigación experimental en Comunicación. Aplicaciones prácticas en persuasión narrativa". In: Carrillo-Durán, María Victoria; Pérez-Pulido, Margarita (coords.). Metodologías y experiencias de investigación en comunicación e información. Tenerife: Sociedad Latina de Comunicación Social, pp. 65-95. ISBN: 9788417314170

Igartua, Juan-José; Barrios, Isabel (2012). “Changing real-world beliefs with controversial movies: processes and mechanisms of narrative persuasion". Journal of communication, v. 62, n. 3, pp. 514-531.

https://doi.org/10.1111/j.1460-2466.2012.01640.x

Igartua, Juan-José; Frutos, Francisco-Javier (2017). "Enhancing attitudes toward stigmatized groups with movies: mediating and moderating processes of narrative persuasion". International journal of communication, v. 11, pp. 158-177. https://ijoc.org/index.php/ijoc/article/view/5779

Igartua, Juan-José; Guerrero-Martín, Iñigo; Cachón-Ramón, Diego; Rodríguez-De-Dios, Isabel (2018). “Efecto de la similitud con el protagonista de narraciones contra el racismo en las actitudes hacia la inmigración: el rol mediador de la identificación con el protagonista". Disertaciones. Anuario electrónico de estudios de comunicación social, v. 11, n. 1, pp. 56-75. https://doi.org/10.12804/revistas.urosario.edu.co/disertaciones/a.5272

Igartua, Juan-José; Rodríguez-Contreras, Laura (2020). "Narrative voice matters! Improving smoking prevention with testimonial messages through identification and cognitive processes". International journal of environmental research and public health, v. 17, n. 19, pp. 7281.

https://doi.org/10.3390/ijerph17197281

Igartua, Juan-José; Vega-Casanova, Jair (2016). "Identification with characters, elaboration, and counterarguing in entertainment-education interventions through audiovisual fiction". Journal of health communication, v. 21, n. 3, pp. 293300.

https://doi.org/10.1080/10810730.2015.1064494

Igartua, Juan-José; Wojcieszak, Magdalena; Cachón-Ramón, Diego; Guerrero-Martín, Iñigo (2017). “'If it hooks you, share it on social networks'. Joint effects of character similarity and imagined contact on the intention to share a short narrative in favor of immigration". Revista latina de comunicación social, v. 72, pp. 1085-1106.

https://doi.org/10.4185/RLCS-2017-1209

Igartua, Juan-José; Wojcieszak, Magdalena; Kim, Nuri (2019). “How the interplay of imagined contact and first-person narratives improves attitudes toward stigmatized immigrants: a conditional process model". European journal of social psychology, v. 49, n. 2, pp. 385-397.

https://doi.org/10.1002/ejsp.2509

Kaufman, Geoff F.; Libby, Lisa K. (2012). "Changing beliefs and behavior through experience-taking”. Journal of personality and social psychology, v. 103, n. 1, pp. 1-19.

https://doi.org/10.1037/a0027525

Kim, Minji (2019). "When similarity strikes back: conditional persuasive effects of character-audience similarity in anti-smoking campaign". Human communication research, v. 45, n. 1, pp. 52-77.

https://doi.org/10.1093/hcr/hqy013

Kovner, Bella; Zehavi, Adar; Golan, Daphna (2021). “Unaccompanied asylum-seeking youth in Greece: protection, liberation and criminalization". The international journal of human rights, online first.

https://doi.org/10.1080/13642987.2021.1874936 
Kreuter, Matthew; Green, Melanie; Cappella, Joseph; Slater, Michael; Wise, Meg; Storey, Doug; Clark, Eddie; O’Keefe, Daniel; Erwin, Deborah; Holmes, Kathleen; Hinyard, Leslie; Houston, Thomas; Woolley, Sabra (2007). "Narrative communication in cancer prevention and control: a framework to guide research and application". Annals of behavioral medicine, v. 33, pp. 221-235. https://doi.org/10.1007/BF02879904

Llopis-Goig, Ramón (2020). “Presentación. Deporte e identidad nacional: articulaciones y desconexiones en contextos postnacionales". Papeles del CEIC, International journal on collective identity research, v. 1, pp. 1-13.

https://doi.org/10.1387/pceic.21471

Llopis-Goig, Ramón; Senyuva, Özgehan; Sonntag, Albrecht (2017). “Le nationalisme n’est plus ce qu'il était. Les formes d'identification contemporaines dans le football européen”. In: Gasparini, William (ed.). L'Europe du football. Sociohistoire d'une construction européenne. Strasbourg: Presses Universitaires de Strasbourg, pp. 155-170. ISBN: 9782868209856

López-Belmonte, Jesús; López-Meneses, Eloy; Vázquez-Cano, Esteban; Fuentes-Cabrera, Arturo (2019). “Avanzando hacia la inclusión intercultural: percepciones de los menores extranjeros no acompañados de centros educativos españoles". Revista de educación inclusiva, v. 12, n. 1, pp. 331-350.

https://revistaeducacioninclusiva.es/index.php/REI/article/view/482

Mar-Molinero, Clare (2001). "Identidad nacional y educación bilingüe en el mundo hispano hablante”. Revista de educación, n. 326, pp. 79-97.

http://www.educacionyfp.gob.es/dam/jcr:86099138-4fb5-4d3b-a0ff-87f008625f73/re32606-pdf.pdf

Mercader, Carla (2019). "40 entidades de vecinos tomarán Barcelona contra la inseguridad”. 20 minutos, 12 septiembre. https://www.20minutos.es/noticia/3761679/0/entidades-vecinos-manifestacion-inseguridad-tsunami-veinal

Ministry of Home Affairs (2020). Informe 2019 sobre la evolución de "los delitos de odio" en España. https://cutt.ly/9IOTnOF

Moyer-Gusé, Emily (2008). "Toward a theory of entertainment persuasion: explaining the persuasive effects of entertainment-education messages". Communication theory, v. 18, n. 3, pp. 407-425.

https://doi.org/10.1111/j.1468-2885.2008.00328.x

Moyer-Gusé, Emily; Dale, Katherine R.; Ortiz, Michelle (2019). "Reducing prejudice through narratives: an examination of the mechanisms of vicarious intergroup contact". Journal of media psychology: Theories, methods, and applications, v. 31, n. 4, pp. 185-195.

https://doi.org/10.1027/1864-1105/a000249

Moyer-Gusé, Emily; Nabi, Robin L. (2010). “Explaining the effects of narrative in an entertainment television program: overcoming resistance to persuasion". Human communication research, v. 36, n. 1, pp. 26-52.

https://doi.org/10.1111/j.1468-2958.2009.01367.x

Müller, Floris (2009). “Entertainment anti-racism: multicultural television drama, identification and perceptions of ethnic threat". Communications. European journal of communication research, v. 34, n. 3, pp. 239-256.

https://doi.org/10.1515/COMM.2009.016

Murrar, Sohad; Brauer, Markus (2018). "Entertainment-education effectively reduces prejudice". Group processes \& intergroup relations, v. 21, n. 7, pp. 1053-1077.

https://doi.org/10.1177/1368430216682350

Nan, Xiaoli; Dahlstrom, Michael F.; Richards, Adam; Rangarajan, Sarani (2015). "Influence of evidence type and narrative type on HPV risk perception and intention to obtain the HPV vaccine". Health communication, v. 30, n. 3, pp. 301-308. https://doi.org/10.1080/10410236.2014.888629

Nan, Xiaoli; Futerfas, Michelle; Ma, Zexin (2017). "Role of narrative perspective and modality in the persuasiveness of public service advertisements promoting HPV vaccination". Health communication, v. 32, pp. 320-328. https://doi.org/10.1080/10410236.2016.1138379

O’Keefe, Daniel J. (2003). “Message properties, mediating states, and manipulation checks: claims, evidence, and data analysis in experimental persuasive message effects research". Communication theory, v. 13, n. 3, pp. 251-274.

https://doi.org/10.1111/j.1468-2885.2003.tb00292.x

Ooms, Joëlle; Hoeks, John; Jansen, Carel (2019). "Hey, that could be me: the role of similarity in narrative persuasion". PloS one, v. 14, n. 4, e0215359.

https://doi.org/10.1371/journal.pone.0215359

Park, Sung-Yeon (2012). "Mediated intergroup contact: concept explication, synthesis, and application". Mass communication \& society, v. 15, n. 1, pp. 136-159.

https://doi.org/10.1080/15205436.2011.558804 
Pettigrew, Thomas F.; Tropp, Linda R. (2006). "A meta-analytic test of intergroup contact theory". Journal of personality and social psychology, v. 90, n. 5, pp. 751-783.

https://doi.org/10.1037/0022-3514.90.5.751

Plener, Paul; Groschwitz, Rebecca; Brähler, Elmar; Sukale, Thorsten; M. Fegert, Jörg (2017). “Unaccompanied refugee minors in Germany: attitudes of the general population towards a vulnerable group". European child \& adolescent psychiatry, v. 26, n. 6, pp. 733-742.

https://link.springer.com/article/10.1007/s00787-017-0943-9

Shapiro, Michael A. (2002). "Generalizability in communication research". Human communication research, v. 28, n. 4, pp. 491-500. https://doi.org/10.1111/j.1468-2958.2002.tb00819.x

Shen, Fuyuan; Sheer, Vivian C.; Li, Ruobing (2015). "Impact of narratives on persuasion in health communication: a meta-analysis". Journal of advertising, v. 44, n. 2, pp. 105-113.

https://doi.org/10.1080/00913367.2015.1018467

Shen, Lijiang (2015). "Targeting smokers with empathy appeal antismoking public service announcements: a field experiment". Journal of health communication, v. 20, n. 5, pp. 573-580.

https://doi.org/10.1080/10810730.2015.1012236

Slater, Michael D.; Rouner, Donna (2002). “Entertainment-education and elaboration likelihood: understanding the processing of narrative persuasion". Communication theory, v. 12, n. 2, pp. 173-191.

https://doi.org/10.1111/j.1468-2885.2002.tb00265.x

Stigel, Jørgen (2001). "TV advertising virtually speaking: the invisible voice elaborating on the space between screen and viewer". In: Agger, Gunhild; Jensen Jens F. (eds.). The aesthetics of television. Aalborg: Aalborg University Press, pp. 321-348. ISBN: 8773076236

Tajfel, Henri (1982). Social identity and intergroup relations. Cambridge: Cambridge University Press. ISBN: 9780521246163

Tukachinsky, Riva (2014). "Experimental manipulation of psychological involvement with media”. Communication methods and measures, v. 8, n. 1, pp. 1-33.

https://doi.org/10.1080/19312458.2013.873777

Valkenburg, Patti M.; Peter, Jochen; Walther, Joseph B. (2016). "Media effects: theory and research". Annual review of psychology, v. 67, pp. 315-338.

https://doi.org/10.1146/annurev-psych-122414-033608

Van-Krieken, Kobie; Hoeken, Hans; Sanders, José (2017). "Evoking and measuring identification with narrative characters - A linguistic cues framework". Frontiers in psychology, v. 8, article 1190.

https://doi.org/10.3389/fpsyg.2017.01190

Vezzali, Loris; Di-Bernardo, Gian-Antonio; Stathi, Sofia; Visintin, Emilio-Paolo; Hewstone, Miles (2019). "Using intercultural videos of direct contact to implement vicarious contact: a school-based intervention that improves intergroup attitudes". Group processes \& intergroup relations, v. 22, n. 7, pp. 1059-1076.

https://doi.org/10.1177/1368430218809885

Vezzali, Loris; Hewstone, Miles; Capozza, Dora; Giovannini, Dino; Wölfer, Ralf (2014). "Improving intergroup relations with extended and vicarious forms of indirect contact". European review of social psychology, v. 25, n. 1, pp. 314-389. https://doi.org/10.1080/10463283.2014.982948

Walter, Nathan; Cohen, Jonathan (2019). "When less is more and more is less: the paradoxical metacognitive effects of counterarguing". Communication monographs, v. 86, n. 3, pp. 377-397.

https://doi.org/10.1080/03637751.2019.1580378

Walter, Nathan; Murphy, Sheila T.; Frank, Lauren B.; Baezconde-Garbanati, Lourdes (2017). "Each medium tells a different story: the effect of message channel on narrative persuasion". Communication research reports, v. 34, n. 2 , pp. 161-170.

https://doi.org/10.1080/08824096.2017.1286471

Wojcieszak, Magdalena; Garrett, R. Kelly (2018). "Social identity, selective exposure, and affective polarization: how priming national identity shapes attitudes toward immigrants via news selection". Human communication research, $\mathrm{v}$. 44, n. 3, pp. 247-273.

https://doi.org/10.1093/hcr/hqx010

Wojcieszak, Magdalena; Kim, Nuri; Igartua, Juan-José (2020). "How to enhance the effects of mediated intergroup contact? Evidence from four countries". Mass communication \& society, v. 23, n. 1, pp. 71-106.

https://doi.org/10.1080/15205436.2019.1630444 